\title{
Maruša Goršak
}

\section{MODULARNO USPOSABLJANJE KARIERNIH SVETOVALCEV - MUKS}

\section{POVZETEK}

$V$ Sloveniji je minilo deset let od prvih poskusov, da bi tudi v našem prostoru oblikovali enoten in celovit formalni izobraževalni program za svetovalce na področju vseživljenjske karierne orientacije. Posamezne organizacije, ki izključno ali kot eno izmed svojih dejavnosti izvajajo storitve vseživljenjske karierne orientacije, so sicer vzpostavile interne sisteme usposabljanja zaposlenih, a do izvedbe prvega skupnega pilotnega usposabljanje kariernih svetovalcev v Sloveniji smo morali počakati še nekaj let. Korak naprej je bil storjen v sklopu projekta »Nacionalna koordinacijska točka za vseživljenjsko karierno orientacijo«, ki je omogočil izvajanje prvega skupnega izobraževanja svetovalcev na področju VKO - Modularnega usposabljanja kariernih svetovalcev, ki je predstavljen $v$ članku.

Ključne besede: vseživljenjska karierna orientacija, izobraževalni program, modularno usposabljanje, karierni svetovalci

\section{MODULAR TRAINING FOR CAREER COUNSELLORS - ABSTRACT}

Exactly ten years have passed since first attempts were made in Slovenia to establish a comprehensive and formalized educational program for counsellors working in the field of lifelong career guidance. In the past, organizations providing (career) guidance services have established their own non-formal employee trainings. A step forward has been made under the framework of the project "National coordination point for lifelong career guidance", which enabled the implementation of the first joint training for (career) guidance counsellors, called Modular training of career counsellors.

Keywords: lifelong career guidance, educational program, modular training, career counsellors 


\section{UVOD}

Ko sem ob koncu študija na Oddelku za pedagogiko in andragogiko Filozofske fakultete v Ljubljani v sklopu diplomske naloge (Goršak, 2011) poskušala utemeljiti potrebo po enotnem strokovnem usposabljanju izvajalcev svetovalne dejavnosti na področju vseživljenjske karierne orientacije (ang. lifelong (career) guidance, ${ }^{1}$ nem. lebensbegleitende Beratung), si nisem predstavljala, da bom nekaj let kasneje tako aktivno sodelovala pri realizaciji prvega celovitega usposabljanja kariernih svetovalcev, t. i. Modularnega usposabljanja kariernih svetovalcev (v nadaljevanju MUKS). In ob zaključku smo skupaj z udeleženci, predavatelji in nosilci projekta lahko upravičeno rekli: »Smo del nove zgodbe - skupaj smo zorali ledino!«

\section{PROFESIONALIZACIJA}

Težnja po večji profesionalizaciji vseživljenjske karierne orientacije ${ }^{2}$ (v nadaljevanju VKO), ki ji sledi večina evropskih držav, govori v prid razvoja sistema izobraževanja in usposabljanja, ki bo vključeval tudi formalno izobraževanje in poklic ter tako zagotovil poklicno kvalifikacijo, ki bo družbeno priznana in ovrednotena. Tudi številne študi$\mathrm{je}^{3}$ ugotavljajo, da je razvitost sistemov izobraževanja in usposabljanja zelo povezana z razumevanjem dejavnosti kot stroke. Eden vodilnih strokovnjakov na področju karierne orientacije, Peter Plant (Plant, 2001), ugotavlja, da se kakovost v različnih državah presoja na podlagi treh kriterijev: kakovosti informacij, kvalifikacij in kompetenc izvajalcev/ praktikov ter storitev oziroma učinkov/rezultatov VKO. Njegovo ugotovitev potrjuje tudi Sultana, ki trdi, »da je usposobljenost osebja eden najvažnejših elementov kakovosti« (Sultana, 2004, str. 98).

1 Pri pregledu tujih in domačih virov lahko opazimo nekonsistentnost pri uporabi in prevajanju angleških terminov »guidance«, »career guidance« in »lifelong career guidance, večina avtorjev pa uporablja definicijo Resolucije iz leta 2004. V nemško govorečih deželah sicer uporabljajo izraz »Beratung «, ki v dobesednem prevodu pomeni svetovanje, pomensko pa vključuje aktivnosti, ki jih zajemata angleška izraza »guidance « in »counselling «. Če želijo poudariti, da gre pri tovrstnih aktivnostih za načrtovanje poklicne poti, pa besedi »Beratung « dodajo ustrezen izraz, npr. »Berufsberatung «, pri čemer »Beruf« pomeni poklic/poklicno. V romanskem delu Evrope uporabljajo besedo orientacija (Francija: orientation, Španija: orientación, Portugalska: orientação, Italija: orientamento, Romunija: orientare) v kombinaciji z ustreznimi pridevniki, ki nakazujejo vsebinski poudarek dejavnosti. Čeprav so bili v zadnjih letih v slovenskem prostoru narejeni veliki premiki k ureditvi terminologije, ne moremo trditi, da obstaja enotno strokovno mnenje o uporabi terminologije, kar pa niti ni tako presenetljivo, saj gre za dokaj mlado področje.

2 V tem prispevku bomo uporabljali definicijo karierne orientacije, kot jo navaja Draft Resolution (2004): »Karierna orientacija (guidance) se v kontekstu vseživljenjskega učenja nanaša na storitve in aktivnosti, ki državljanom v vseh starostnih obdobjih in na katerikoli točki njihovega življenja omogočajo identifikacijo njihovih sposobnosti, kompetenc in interesov za odločanje na področju izobraževanja, usposabljanja in izbire poklica. Poleg tega jim omogočajo vodenje njihovih življenjskih poti v učenju, delu in drugih okoljih, v katerih se teh sposobnosti in kompetenc naučijo in/ali jih uporabljajo.«(Draft Resloution ... 2004, str. 2-3)

3 Izboljšanje politik in sistemov vseživljenjske karierne orientacije (2006), Career guidance and public policies - bridging the gap (2004), Sultana (2004), From policy to practice (2008), Professionalising career guidance (2009) idr. 
Resolucija sveta EU (Council Resolution on better ..., 2008), kjer je zagotavljanje kakovosti storitev vseživljenjske karierne orientacije poudarjeno kot eno izmed štirih prednostnih nalog evropskega sodelovanja na tem področju, pa med drugim priporoča, naj države članice poskrbijo za kakovost storitev $\mathrm{s}$ »povečanjem profesionalizacije osebja in zagotovijo minimalne standarde tudi z začetnim in nadaljevalnim usposabljanjem« (prav tam, 2008, str. 6).

\section{ZAČETKI IZOBRAŽEVALNIH PROGRAMOV}

V Sloveniji je minilo deset let od prvih poskusov, da bi tudi v našem prostoru oblikovali enoten in multidisciplinaren izobraževalni program za svetovalce na področju VKO. Prvi korak je naredila medresorska skupina, ki je delovala v sklopu naloge »Razvijanje in širjenje mreže z IKT podprtih lokalnih/regionalnih svetovalnih centrov in centrov za poklicno svetovanje ter točk za vseživljenjsko učenje«. V sklopu naloge »Priprava skupnega programa usposabljanja za svetovalne delavce $v$ svetovalnih omrežjih za načrtovanje in vodenje kariere « je tako nastala prva nacionalna opredelitev skupnih vlog in kompetenc svetovalcev v različnih omrežjih, na podlagi katere so bile oblikovane vsebine okvirnih splošnih in specifičnih izobraževalnih modulov. Že takrat je delovna skupina predlagala, da bi bilo tudi v slovenskem prostoru smiselno pripraviti skupen sistem usposabljanja za strokovne delavce v različnih svetovalnih omrežjih, a se to ni uresničilo (Kohont, 2006, Polak Williams, 2011). Posamezne organizacije, ki izključno ali kot eno izmed svojih dejavnosti izvajajo storitve VKO, so sicer vzpostavile interne sisteme usposabljanja svetovalcev, ta usposabljanja pa so bila pogosto usmerjena na potrebe specifične ciljne skupine strank, zaradi pomanjkanja finančnih sredstev pa v večini tudi omejenega trajanja. Do izvedbe prvega skupnega pilotnega usposabljanje kariernih svetovalcev v Sloveniji smo tako morali počakati še nekaj let.

Do premika je prišlo v sklopu projekta »Nacionalna koordinacijska točka za vseživljenjsko karierno orientacijo « (v nadaljevanju NKT VKO), katerega nosilec je Zavod RS za zaposlovanje. Projekt je dal zagon številnim aktivnostim, ki pomenijo korak naprej k večji profesionalizaciji karierne orientacije, končni rezultat pa je bilo pilotno Modularno usposabljanje kariernih svetovalcev. $\mathrm{V}$ tem projektu je bila $\mathrm{v}$ našem prostoru prvič opravljena tudi Analiza o interesu potencialnih delodajalcev za izobraževanje kariernih svetovalcev (Niklanovič, 2011). Uporabljen je bil polstrukturiran intervju (vprašalnik z devetimi vprašanji), intervjuvanci pa so bili predstavniki organizacij/delodajalcev, ${ }^{4}$ kjer se zaposleni svetovalci primarno ali kot del svoje službe ukvarjajo z razvojem kariere svojih strank. Vseh 21 predstavnikov organizacij je menilo, da v Sloveniji potrebujemo izobraževalni program, ki bi svetovalcem dal specializirane kompetence za delo na področju karierne orientacije, analiza pa je opozorila tudi na nekatere dileme (vpisni pogoji, vključevanje pridobljene kvalifikacije v sistem kadrovanja itd.) (prav tam).

4 Med intervjuvanci so bili: ravnatelji osnovnih in srednjih šol, ravnatelji/vodje v izobraževanju odraslih, direktorji Zavoda za zaposlovanje RS Slovenije (ZRSZ), vodje kadrovskih služb v podjetjih, direktorji agencij za zaposlovanje, ministrstvo za delo, družino in socialne zadeve (MDDSZ), Zavod Republike Slovenije za šolstvo, Univerza v Ljubljani (vodja Kariernega centra Univerze v Ljubljani). 


\section{KOMPETENČNI MODEL}

V predhodni fazi je bil v sodelovanju s Pedagoško fakulteto Univerze v Ljubljani oblikovan kompetenčni model, ki je vključeval splošne ter predmetno specifične kompetence, ki naj bi jih izvajalci vseživljenjske karierne orientacije razvijali v okviru izobraževanja. Oblikovane so bile osnovne vsebine izobraževanja, razporejene v šest modulov:

- Teorije kariernega razvoja;

- Dejavnosti kariernega razvoja;

- Skupinske oblike dela v karierni orientaciji;

- Osebnostni razvoj;

- Dejavnosti karierne orientacije;

- Raziskovanje in evalvacija.

Poskusi uvajanja izobraževalnega programa $\mathrm{v}$ okviru ene od fakultet se spet niso posrečili, zato se je nosilec projekta odločil, da pilotno usposabljanje kariernih svetovalcev izvede kot neformalno izobraževanje. Usposabljanje je bilo tako razvito na podlagi dveh kompetenčnih modelov (kompetenčni model NICE in kompetenčni model, ki ga je razvila Pedagoška fakulteta), ki opisujeta kompetence izvajalcev vseživljenjske karierne orientacije (Rutar Leban, Štremfel, Mlekuž, 2015).

Glavni namen Modularnega izobraževanja kariernih svetovalcev je bil: a) okrepiti zavedanje kariernih svetovalcev o pomenu kariere za kakovostno življenje posameznika, za družbeni napredek in zagotavljanje socialne pravičnosti; b) povezovati svetovalce, zaposlene na različnih področjih dela, ter krepiti njihovo poznavanje skupnih točk in razlik in c) usposabljati svetovalce za delo z različnimi metodami dela in jih seznanjati z njihovim teoretičnim ozadjem. Pred izvedbo je nosilec projekta NKT VKO opravil analizo potreb med svetovalci in potencialnimi udeleženci izobraževalnega programa, v kateri je sodelovalo 404 svetovalcev. Tako so želeli preveriti, ali so načrtovane izobraževalne teme ustrezne in ali bi se anketiranci tovrstnega izobraževanja udeležili (Vprašalnik o interesu ciljnih skupin za vključitev v študijski program karierne orientacije: Analiza odgovorov na vprašanja). Na podlagi rezultatov je nosilec projekta pripravil okvir obveznih vsebin nastajajočega izobraževalnega programa.

\section{MODULARNO USPOSABLJANJE}

Modularno usposabljanje kariernih svetovalcev je obsegalo 160 ur, pri čemer je bilo 140 ur namenjenih splošnim modulom, udeleženci pa so lahko izbrali enega od štirih specialnih modulov, ki so se razlikovali glede na ciljno skupino uporabnikov (zaposleni, mladi, iskalci zaposlitve, ranljive skupine).

Navajamo splošne module $\mathrm{s}$ temeljnimi vsebinskimi temami in obsegom ur.

Splošni modul 1: Vseživljenjska karierna orientacija kot stroka (14 ped. ur)

- Uvod v VKO

- Družbeni vidiki VKO 
Splošni modul 2: Svetovanec in svetovalec v procesu svetovanja (40 ped. ur)

- Svetovalni proces in zgodovinski razvoj

- Komunikacija v svetovalnem procesu

- Karierno odločanje

- Svetovalno delo v praksi

- Delo svetovalca

Splošni modul 3: Teorije, modeli in metode ter pripomočki (55 ped. ur)

- Karierni razvoj

- Svetovalni intervju

- Dodatne tehnike in pristopi za vodenje individualnega svetovanja

- Spoznavanje in praktična uporaba metod in pripomočkov I, II, III

- Konstruktivistični model in pripovedna tehnika v kariernem svetovanju

Splošni modul 4: Družbene skupine in skupinske oblike dela v vseživljenjski karierni orientaciji (31 ped. ur)

- Značilnosti družbenih skupin v VKO in skupinske oblike dela

- Skupinska dinamika

- Praktična uporaba skupinskih metod dela

- Promocija VKO

Specialni moduli so obsegali po 20 ped. ur in so bili naslednji:

- Specialni modul za kadrovske strokovnjake (izveden dvakrat),

- Specialni modul za šolske svetovalne delavce,

- Specialni modul za svetovalce v zaposlovanju,

- Specialni modul za svetovalce v nevladnih organizacijah (se ni izvajal).

Čeprav se Modularno usposabljanje kariernih svetovalcev uvršča med neformalno izobraževanje in tako ne omogoča pridobitve poklicne kvalifikacije, pa je bila zasnova vseeno pripravljena v skladu s priporočili za oblikovanje formalnih programov izobraževanja s področja VKO. Kot je navedeno v publikaciji Professionalising career guidance (2009), naj bi bili tovrstni programi organizirani tako, da ponujajo skupne vsebine, ob tem pa je možno izbrati tudi predmete/module, ki so vsebinsko vezani na delovanje znotraj posameznega sektorja (npr. izobraževanje, delo in zaposlovanje, privatni in nevladni sektor). Skupne vsebine programa imajo namreč velik vpliv na razvoj skupne poklicne identitete, pripomorejo tudi k boljšemu sodelovanju in usklajevanju med sektorji, zaposleni pa bodo po zaslugi povečane mobilnosti med sektorji dobili možnost, da tudi sami bolj prožno načrtujejo lastno kariero (Professionalising career guidance, 2009).

Za izvajalca programa je bilo na javnem razpisu izbrano podjetje Kadis, d. o. o., ki je usposabljanje izvajalo v sodelovanju s podjetjem O.K. Consulting v obdobju od decembra 2014 do junija 2015. Modularnega usposabljanja kariernih svetovalcev se je udeležilo 59 kariernih svetovalcev, ki se pri svojem delu ukvarjajo z razvojem kariere svojih strank. $\mathrm{V}$ treh skupinah (dve sta se srečevali med vikendom, ena pa v dopoldanskem času med tednom) so si znanje in izkušnje izmenjevali svetovalci s področja izobraževanja, zapo- 
slovanja, kadroviki, svetovalci iz nevladnih organizacijah itd. Pred vključitvijo v program smo z večino udeležencev izvedli uvodni intervju, s čimer smo želeli identificirati njihova pričakovanja, izkušnje in izzive, s katerimi se srečujejo pri svojem delu, ter predznanje glede na predvidene vsebine. In čeprav je analiza potreb, ki jo je predhodno opravil nosilec projekta, pokazala, da le polovica anketirancev meni, da je tema »teorije in koncepti kariernega razvoja « pomembna ali zelo pomembna za njihovo delo, smo v uvodnih intervjujih ugotovili, da je veliko bodočih udeležencev MUKS s teoretičnim ozadjem razvoja kariere slabše seznanjena, predvsem pa so le redki pri svojem delu uporabljali novejše teorije. Del programa je bil tako namenjen izključno spoznavanju različnih teoretskih ozadij kariernega svetovanja in kariernega razvoja, ki smo jih nato skozi celotno izobraževanje povezovali s konkretnimi pristopi in orodji.

\section{RAZNOLIKE METODE}

V MUKS smo gostili širok nabor domačih predavateljev, kar je udeležencem omogočalo spoznavanje novih metod in pristopov ter seznanjanje $\mathrm{z}$ delom $\mathrm{v}$ karierni orientaciji $\mathrm{v}$ različnih okoljih, organizacijah in kontekstih. Gostili smo tudi posebno gostjo, dr. Hazel Reid, ki nam je predstavila konstruktivistični pristop in uporabo pripovedne (narativne) tehnike v kariernem svetovanju.

V MUKS so lahko udeleženci prvič na enem mestu dobili najširši spekter znanj in veščin na področju vseživljenjske karierne orientacije. Ves čas usposabljanja so imeli tudi dostop do e-platforme, kjer je bilo naloženo gradivo, uporabljeno v sklopu usposabljanja (gradivo s predavanj, vaje, dodatna literatura, samostojne naloge udeležencev ipd.). Z namenom razvoja kompetenc je MUKS udeležencem omogočal še do pet ur individualnega coachinga. Spodbujali smo jih tudi k uporabi t. i. učnega dnevnika, s čimer smo jih želeli motivirati za sprotno vrednotenje svojega učenja, razmišljanje o prenosu znanja v prakso in identifikacijo morebitnih manjkajočih kompetenc. Aktivne oblike dela ter preizkušanje različnih vaj in orodij so imeli po mnenju udeležencev poleg razvoja kompetenc tudi druge pozitivne (stranske) učinke, saj jih je »izobraževanje prisililo v samorefleksijo o svojem delu, v razmišljanje o sebi«, kot je bilo ugotovljeno v evalvaciji. Izobraževanje je vplivalo tako na njihov osebni razvoj kot na njihovo delo - in na ta način so skozi izobraževanje vedno iskali možnosti za izboljšanje svojega dela (Rutar Leban idr., 2015). Poleg tega so udeleženci kompetence, pridobljene skozi izobraževanja, ocenili precej visoko (povprečne ocene so višje od 3,5 na lestvici z najvišjo oceno 5), kar kaže na prevladujoče mnenje, da bi na podlagi pridobljenega znanja znali razmeroma dobro ocenjevane aktivnosti izpeljati tudi v praksi (prav tam).

\section{EVALVACIJA PROGRAMA}

MUKS se je poskušal približati »kriteriju« zagotavljanja učinkovitosti izobraževalnih programov s področja VKO, ki govori o tem, da je: »karierna orientacija dejavnost, kjer je razvoj veščin in spretnosti zelo poudarjen, zato morajo biti tudi izobraževalni programi 
zasnovani tako, da poleg širokega teoretičnega zaledja ponujajo možnosti/osnovo za razvoj temeljnih poklicno specifičnih spretnosti in kompetenc « (Career guidance and public policy ..., 2004, str. 94).

Končna evalvacija programa, ki jo je je opravil Pedagoški Inštitut, je v večini potrdila uspešnost MUKS z vidika zadovoljstva udeležencev in vključenosti večine kompetenc iz obeh kompetenčnih modelov (kompetenčni model NICE in kompetenčni model, ki ga je razvila Pedagoška fakulteta) v izvedbeni načrt usposabljanja (Rutar Leban idr., 2015).

Udeleženci so poleg izpolnjevanja anketnih vprašalnikov sodelovali tudi v fokusnih skupinah, kjer so kot prednost poudarili heterogenost skupin, ki je pripomogla k vzajemnemu učenju prek izmenjave izkušenj ter spodbudila povezovanje različnih institucij, iz katerih so prihajali udeleženci. Udeleženci so cenili tudi strokovnost predavateljev in praktično vrednost obravnavanih vsebin, saj so večino vaj že naslednji dan lahko uporabili v praksi. Pogrešali so več možnosti za razvoj medkulturne kompetence, saj se pri svojem delu vedno bolj pogosto srečujejo s pripadniki različnih kultur (prav tam). Predvsem pa so si želeli, da bi bilo usposabljanje formalizirano, a hkrati si mnogi ne želijo, da bi izvajanje prevzele akademske institucije. V drugih evropskih državah tovrstna izobraževanja za karierne svetovalce namreč pogosto zagotavljajo visokošolske ustanove. Slovenija je tako še vedno ena redkih držav EU, ki nima formalnega izobraževalnega programa, ki bi diplomante usposabljal za delo na področju VKO. Kot ugotavlja Polak Williams (2011), svetovalci menijo, »da osnovno izobraževanje, ki ga strokovni delavci pridobijo v času študija, ni zadostno za opravljanje del in nalog na področju načrtovanja in vodenja kariere« (Polak Williams, 2011, str. 15).

\section{ZAKLJUČEK}

MUKS je opozoril tudi na potrebo po ustrezno in formalno usposobljenih svetovalcih za pomoč posameznikom pri načrtovanju in vodenju kariere na sodobnem, spreminjajočem se trgu dela. Ljudje smo namreč naravnani tako, da pogosteje uporabljamo metode in pristope, za katere smo se lahko ustrezno usposobili. Zaključimo lahko spodbudno. Čeprav se je projekt končal, udeleženci Modularnega usposabljanja kariernih svetovalcev - MUKS-evci pišejo zgodbo še naprej. Mreža, ki se je vzpostavila, ohranja stike, tako na poslovni kot tudi na osebni ravni. Ideja o rednih mesečnih srečanjih, kjer bi obravnavali aktualne tematike s področja VKO, še ni zaživela, a verjetno bo. Več o projektu in vsebinah si lahko preberete na spletni strani projekta »Nacionalna koordinacijska točka za vseživljenjsko karierno orientacijo«.

\section{LITERATURA}

Career guidance and public policy - bridging the gap. (2004). OECD. Pridobljeno s http://www.oecd. org/dataoecd/33/45/34050171.pdf.

Council Resolution on better integrating lifelong guidance into lifelong learning strategies. (2008). Bruselj: Svet Evropske unije. 
From policy to practice: A systemic change to lifelong guidance in Europe. (2008). CEDEFOP. Pridobljeno s http://www.cedefop.europa.eu/etv/Upload/Information_resources/Bookshop/505/5182_en.pdf.

Goršak, M. (2011). Strokovno usposabljanje za poklicno orientacijo (Diplomsko delo). Ljubljana: Filozofska fakulteta.

Izboljšanje politik in sistemov vseživljenjske karierne orientacije. Uporaba skupnih referenčnih orodij. (2006). Ljubljana: Zavod RS za zaposlovanje.

Kohont, A. (2006). Skupne kompetence svetovalnih omrežij v procesu vseživljenjskega učenja v Sloveniji (Interno gradivo). Ljubljana: CPI.

Niklanovič, S. (2011). Analiza interesa delodajalcev za zaposlovanje kariernih svetovalcev. Ljubljana: Univerza v Ljubljani, Pedagoška fakulteta. Pridobljeno s http://www.ess.gov.si/o_zrsz/projekti_zavoda/nkt/izobrazevanje.

Plant, P. (2001). Quality in Careers Guidance. OECD. Pridobljeno s http://www.oecd.org/dataoecd/35/47/2698228.pdf.

Polak Williams, M. (2011). Analizi dosedanjega izobraževanja s področja karierne orientacije. Nacionalna koordinacijska točka za vseživljenjsko karierno orientacijo. Ljubljana: Zavod RS za zaposlovanje. Pridobljeno s http://www.ess.gov.si/o_zrsz/projekti_zavoda/nkt/izobrazevanje.

Professionalising career guidance: Practitioner competences and qualification routes in Europe. (2009). CEDEFOP. Pridobljeno s http://www.cedefop.europa.eu/etv/Upload/Information_resources/ Bookshop/531/5193_en.pdf.

Rutar Leban, T., Štremfel, U., Mlekuž, A. (2015). Evalvacija modularnega izobraževanja za karierne svetovalce, izdelanega v okviru JN št. 4300-23/2014. Končno poročilo. Nacionalna koordinacijska točka za vseživljenjsko karierno orientacijo. (Interno gradivo). Ljubljana: Zavod RS za zaposlovanje.

Sultana, R.G. (2004). Guidance Policies in the Learning Society - Trends, Challenges and Responses across Europe. CEDEFOP Synthesis report. Pridobljeno s http://www2.trainingvillage.gr/etv/publication/download/panorama/5152_en.pdf.

Vprašalnik o interesu ciljnih skupin za vključitev v študijski program karierne orientacije: Analiza odgovorov na vprašanja. Nacionalna koordinacijska točka za vseživljenjsko karierno orientacijo. Ljubljana: Zavod RS za zaposlovanje. Pridobljeno s http://www.ess.gov.si/o_zrsz/projekti_zavoda/nkt/ izobrazevanje. 